таможенного реестра объектов интеллектуальной собственности»;

4. Шурыгин С.Н. Борьба с контрафактом: тест на эффективность // Таможня - №6. - март.-2006 г. c. 22

5. Лепихов Г.В. Таможня и бизнес: против контрафакта вместе // Экономика и жизнь. - № 1. январь. - 2007г. - с. 25 6. Воробьева Г.Н. Защита прав интеллектуальной собственности - один из приоритетов деятельности ФТС // Консультант. №21. - ноябрь. - 2006 г. - с. 25

7. Будаева Е.В. Как обеспечить права интеллектуальной собственности //Таможня. сентябрь. -2006 г. - с. 12

8. https://ru.wikipedia.org/wiki/Товарный_знак

\title{
FEATURES OF THE INTERNATIONAL COOPERATION IN SEARCH OF THE PERSONS WHO HAVE COMMITTED CORRUPTION CRIMES
}

\author{
Matchanov Alimjan Atabaevich \\ The doctor of jurisprudence, the senior lecturer, \\ professors of chair of preliminary investigation and criminalistics of Academy \\ of the Ministry of Internal Affairs of Republic Uzbekistan, \\ 100197, Republic Uzbekistan, Tashkent, street Intizor, 68 \\ DOI: $10.31618 /$ nas.2413-5291.2020.2.56.244
}

\section{The summary}

In given article problems of international legal regulation of the mechanism of searching persons committed corruption crimes, features of cooperation, coordination of joint actions of the states among themselves and with the international organisations which are carrying out fight against corruption are considered. On the basis of the conducted research the conclusion about necessity of perfection of the criminally-remedial mechanism of searching persons committed the corruption crimes, making direct impact on optimisation of technology of the international search of disappearing criminals becomes.

Keywords: The International search, corruption crimes, technology of search, state law enforcement bodies, the international cooperation.

In the modern world, the criminality oversteps the bounds of the separate state and gets transnational character. It concerns and corruption crimes, counteraction which infringes on interests of almost all countries. One of the problems is searching persons, committed corruption crimes which in the majority disappear outside of the state, where the crime has been committed. The mechanism of the international cooperation and interaction of subjects of search is necessary for their search, detention and the subsequent extradition, both on national and at interstate level.

Optimisation of procedure of the international searching persons who committed corruption crimes, their detention and the subsequent extradition, presses perfection of the mechanism of the organisation of cooperation (interaction) of countries in the given sphere. In our opinion this process is necessary for improving in two basic directions: is standard-legal regulation of the mechanism of interstate searching persons, put on the international wanted list, and, in coordination of the corresponding international organisations in activity of the national bodies responsible for results of searching.

According to criminally-remedial and the operatively-search legislation employees of criminal investigation department carry out direct search and detention of criminals put on the international wanted list. According to D.E. Karimova's opinion in current CCP of Uzbekistan the optimum remedial mechanism of interaction of the inspector with criminal investigation department divisions is not settled, «there are only inclinations of the given mechanism, but the remedial order of interaction does not meet modern requirements» $[1$, p. 39.].
The success of each country and all world community of the independent states, in corruption counteraction, develops of total of the criminal cases which have come to the end with successful search and attraction of criminals to a criminal liability. At deliberate evasion of criminals from investigation, by means of shelter in other countries, there is a necessity of cooperation of the states for realisation of the international search for, persons guilty of corruption and the decision of a question on their extradition. D.S. Umarhanova offers to accept Typical United Nations contracts «About creation operatively-investigation teams», "the regulating relation on an exchange of the operative information for search of criminals, gathering or search of proofs, joint actions of the authorised bodies of the states» [2, p. 45.], with a view of maintenance of inevitability of responsibility for fulfilment of transnational crimes (including corruption).

In Uzbekistan searching persons, who committed corruption crimes, is regulated section 14 «the International cooperation in sphere of criminal legal proceedings» УПК (item 592-609 item), and also multilateral and bilaterial contracts. A version of the last one is interstate search, which is carried out within the CIS (the near abroad country). While the international search is carried out in territories of other states (the far abroad country).

Such special international certificate, directly regulating cooperation in the organisation of people search who have committed crimes, the Contract of the states-participants of the Commonwealth of Independent States (further the CIS) about interstate search [3] is confirmed in May, 2011. Besides there are also other, universal international documents which 
concern search and delivery of the persons who have committed crimes: «The typical extradition treaty»; «The typical contract on mutual aid in the field of criminal justice», etc. [4].

Concerning legal regulation of interstate both international search V.P. Illarionov and I.V. Putova specify that this search based on international law sources, namely on the international contracts $[5, \mathrm{p} .8]$, except the national legislation.

The specified contracts of the CIS countries are directed on realisation of effective interaction of competent law enforcement bodies of the countries of commonwealth. Concerning it S.E. Erkenov notices that they spend «assistance in realisation of interstate search of participants of criminal communities, the persons committed the most dangerous crimes and disappearing from criminal prosecution» $[6, \mathrm{p} .24]$.

In the course of interstate, international searching persons committed corruption crimes the complex criminally-remedial, international legal, organizational and operatively-search are realized. A special role in search process the international organisations of criminal police, such as occupy the Interpol, the Eurofloor, with Americapol and some other, coordinating, systematising international the searching persons who committed crimes of a corruption orientation.

According to official figures, cooperation of the CIS countries in struggle against the organised crime, including in search persons who committed crimes, connected with corruption counteraction, was fruitful last years. Law enforcement bodies plan to open more crimes, by active international cooperation. In our opinion, now it is necessary to develop the effective mechanism of the international cooperation in detection, detention and an extradition of persons declared in the international (interstate) search. In this respect the organisation of the given kind of search assumes perfection of a legal ground by means of working out of the uniform multilateral contract on the international searching persons who committed crimes, by an example of the similar contract of the countries of Commonwealth of the independent states (CIS) about interstate search about which already there was a speech earlier. Inherently international and interstate contract are homogeneous, differing basically to a territorial sign. Concerning this A.V. Dunaev notices that «interstate search is a version of the international search which is carried out by the same actions, means and with the same purpose, but in territory of two states at the initiative of law enforcement bodies of one of the specified states» $[7, \mathrm{p} .85]$. Acceptance of the similar contract within the limits of the world community or Interpol would make essential impact on efficiency of cooperation in adjustment of the international persons search that committed crimes.

N.G. Gasymov, analyzing the reasons allocates two main things which have caused occurrence of the international search: 1) display and active growth of transnational criminality; 2) the conventional principle in sphere of cooperation of the states in struggle against criminality - respect of the national sovereignty of the countries-participants according to which law enforcement bodies of one state cannot operate in territory of another [8, p.35].

In this respect it is possible to result I.V. Putova's defining opinion that «the international search of criminals in modern conditions of development and an intensification of international contacts is one of the major directions of cooperation of the states ...» $[9$, p.9]. In our opinion, time for perception of the international search as complex, many-sided, including technological process national criminally-remedial, criminalistic, operatively-search and international law has come.

The above-stated opinions are worthy, but in our opinion they are necessary for correcting, having brought specification that the search mechanism, is connected with features of objects of search - the persons committed a certain kind of a crime and declared in interstate or international search. In our opinion, it is necessary to understand activity of corresponding law-enforcement structures of the statesparticipants allocated with powers of realisation of complex search, operatively-search and internationalorganizational actions under the available requirement of the country, the initiator of search as these kinds of search, in territory of the countries-participants, at registration of corresponding documents on detention disappearing and imprisonment or other preventive punishment.

Thus, on the basis of the above-stated, it is possible to draw a conclusion that the international searching persons that committed corruption crimes including search spent within the limits of INTERPOL, the interstate search which is carried out in the CIS countries, in modern conditions in insufficient degree answers shown conditions and insistently is required perfection of a criminally-remedial order, criminalistic tactics in the conditions of new realities of scientific and technical progress, innovative technologies making essential impact on optimisation of the mechanism of the international searching disappearing criminals.

\section{The list of references:}

1. Karimova D.E. «Perfection of interaction of the inspector of law-enforcement bodies with criminal investigation department divisions»: Syn. ... Dr.s of philosophy (PhD). - T, 2018. - 54 p.

2. Umarhanova D.SH. «Perfection of the mechanism of the international cooperation on criminal cases»: Syn.. ... dock. legal. Sciences (DSc). - T, 2018. $-78 \mathrm{p}$.

3. The Contract of the states-participants of the Commonwealth of Independent States «About interstate search of persons» Moscow, on December, 10th, 2010//the Collection of the international contracts of Republic Uzbekistan, 2012, № 1-2. Has come into force for Republic Uzbekistan on August, 24th, 2011

4. The Resolution of the United Nations 45/116; the Resolution of the United Nations 45/117; the Convention on struggle against illegal capture of aircrafts signed in the Hague on December, 16th, 1970; the Uniform convention on the narcotics, confirmed on March, 30th 1961г.; the Convention of the Shanghai 
organisation of cooperation against terrorism from June, 16th, 2009, etc.

5. Illarionov V.P, Putova I.V. «Legal and organizational-methodical aspects of the international searching criminals». The manual. - M: the Book world, 1999. - 94 pages.

6. Erkenov S.E. Interaction of law enforcement bodies of the CIS countries at disclosing and investigation of transnational crimes: Syn. Dr.s legal.. Sciences. - M, 2000. -48 p.
7. Dunaev A.V. About concepts of interstate and international kinds of search / of A. V. Dunaeva.//Psychopedagogics in law enforcement bodies. - 2013. - № 1. - P. 85.

8. Gasymov Nijazi Gara «The International search: theory and practice questions» : Syn. Dr.s legal. Sciences. - M, 2005. - 49 p.

9. Putova I.V. «International search of criminals: legal, organizational, operational and tactical aspects»: Syn. Sciences. - M, 2001. -23 p.

\section{СПЕЦИФИКА МЕХАНИЗМА И СПОСОБОВ ПРЕСТУПЛЕНИЙ В СФЕРЕ СОЦИАЛЬНОГО ОБЕСПЕЧЕНИЯ}

\section{Резюме}

Нургалиев Б. М.

д.ю.н., профессор, Академия «Болашак», Казахстан, г. Караганда

Нургалиев Б.Б., к.ю.н.,

Карагандинская академия МВД РК

B.M. Nurgaliyev
Doctor of Sciences (Law),
professor Academy “Bolashak”,
Karaganda, Kazakhstan
B.B.Nurgaliyev
Candidate of Sciences (Law),
Karaganda Academy
of the Ministry of Internal Affairs of the RK,
Karagandy
DOI: $10.31618 /$ nas.2413-5291.2020.2.56.240

В данной статье рассматриваются отдельные проблемы расследования преступлений в сфере социального обеспечения, основанных на совершении мошеннических действий. В статье на основе криминалистической литературы и анализа судебно-следственной практики раскрываются некоторые аспекты криминалистически значимой информации о способах, а также механизме мошеннических действий.

\section{Abstract}

This article discusses certain problems of investigation of crimes in the field of social security based on the commission of fraudulent acts. Based on the forensic literature and the analysis of forensic investigative practice, the article reveals some aspects of forensically significant information about the methods and the mechanism of fraudulent actions.

Ключевые слова: следственная ситуация; механизм совершения преступления; способ совершения преступления; социальная сфера; социальные выплаты; мошенничество.

Key words: investigative situation; mechanism for committing a crime; method of committing a crime; social sphere; social payments; fraud.

Введение. Бюджетная сфера, а в ее составе сфера социального обеспечения и выплат как направление финансовой политики государства является одной из наиболее притягательных для совершения в её среде криминальных действий. В особенности, людей, получающих адресную социальную помощь (АСП), за всю историю независимости Казахстана никогда столько не было - а это более 1 млн. 800 тысяч, из всего 8 млн. работоспособных налогоплательщиков[1]. Противоправные деяния совершаются как отдельными лицами, так и организованными преступными группами. При этом субъекты, совершающие такого рода преступления, имеют должные знания в области финансового регулирования, распределения бюджетных средств на местах, а также выполняют определённый комплекс действий, направленных на движение денежных средств соответствующих бюджетов [2].

За последних 3.5 года антикоррупционной службой (финансовая полиция) зарегистрировано 322 коррупционных преступления в сфере социальной защиты населения (2016 г. - 70, 2017 г. - 126, 2018 г. - 82, а за 5 мес. 2019 г. - 44). В суд было направлено 188 дел. По ним осуждены к различным видам наказания 69 должностных лиц. Только в одной Карагандинской области выявлены хищения бюджетных средств в размере 107,1 млн. тенге путем незаконного начисления пенсионных выплат жителям области за денежное 